\title{
Middle Miocene rockling (Teleostei, Gadidae) from the Paratethys (St. Margarethen in Burgenland, Austria)
}

\author{
GIORGIO CARNEVALE \& MATHIAS HARZHAUSER
}

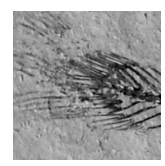

\begin{abstract}
Fishes of the subfamily Gaidropsarinae, commonly known as rocklings, are anatomically unique within the family Gadidae (Teleostei, Gadiformes), mostly because of their possession of a highly specialized chemosensory and vibratile first dorsal fin. The genus Gaidropsarus contains 13 extant species occurring from subtropical to temperate waters in the North Atlantic, Mediterranean, South Africa, New Zealand, Tasmania, Japan and southeastern Pacific, plus a single fossil species from the Miocene of Algeria. A new species of rockling, Gaidropsarus pilleri sp. nov., is described from the Middle Miocene (Late Badenian) corallinacean limestone of St. Margarethen in Burgenland, Eisenstadt-Sopron Basin, Austria based on seven articulated skeletons. The new species is based on a unique combination of features, including: possession of a wide neurocranium (neurocranial width contained less than two times in its length); well-developed sphenotic spine; epibranchials 2 and 3 characterized by massive uncinate processes; presence of $44(13+31)$ vertebrae; five posterior parapophyses enlarged, the posterior three wing-like; $2^{\text {nd }}$ dorsal fin contains about 50 rays; anal fin with 43 rays; caudal peduncle very short $(2.4 \%$ SL). Gaidropsarus pilleri sp. nov. is the earliest known occurrence of the rocklings based on skeletal remains. The vibratile and chemosensory first dorsal fin of gaidropsarines may have arisen by co-option of the first dorsal-fin module. $\bullet$ Key words: Teleostei, Gadiformes, Gadidae, Gaidropsarus pilleri, Middle Miocene, Badenian, St. Margarethen in Burgenland, Eistenstadt-Sopron Basin, Austria.
\end{abstract}

Carnevale, G. \& Harzhauser, M. 2013. Middle Miocene rockling (Teleostei, Gadidae) from the Paratethys (St. Margarethen in Burgenland, Austria). Bulletin of Geosciences 88(3), 609-620 (7 figures, 2 tables). Czech Geological Survey, Prague. ISSN 1214-1119. Manuscript received March 14, 2013; accepted in revised form April 16, 2013; published online May 29, 2013; issued July 3, 2013.

Giorgio Carnevale, Dipartimento di Scienze della Terra, Università degli Studi di Torino, Via Valperga Caluso, 35 I-10125 Torino, Italia; giorgio.carnevale@unito.it - Mathias Harzhauser, Geologisch-Paläontologische Abteilung, Naturhistorisches Museum in Wien, Burgring 7, A-1010 Vienna, Austria

The gaidropsarines, commonly known as rocklings, constitute a monophyletic assemblage of bottom-living gadid fishes that occur from the intertidal zone to the deep-sea. This small group includes three genera, among which Gaidropsarus is by far the most diverse with 14 recognized species (see Svetovidov 1986, Carnevale 2007). The genus Gaidropsarus is the only member of the group characterized by a bipolar distribution (Howes 1991), with species that occur in subtropical to temperate waters in the North Atlantic, Mediterranean, South Africa, New Zealand, Tasmania, Japan and southeastern Pacific. More than half of the known species occur in the northern hemisphere, mostly in the north-eastern Atlantic and the Mediterranean. Articulated skeletal remains of gaidropsarines are extremely rare in the fossil record, apparently represented by a single partially complete individual from the Messinian of the Chelif Basin, Algeria (Carnevale 2007). The goal of this paper is to describe a new species of the genus Gaidropsarus from the
Middle Miocene corallinacean limestone of St. Margarethen in Burgenland, Eisenstadt-Sopron Basin, Austria.

Fossil fishes from the corallinacean limestone cropping out in the surroundings of the St. Margarethen in Burgenland village are known since the first half of the $19^{\text {th }}$ century (see Münster 1846) and several specimens were described at that time by celebrated Austrian naturalists such as J.J. Heckel and R. Kner (Heckel 1950, 1856; Heckel \& Kner 1861; Kner 1862). A very large collection of these finely preserved fossil fishes is currently housed in the Naturhistorisches Museum in Vienna and only a small part has been studied (Bachmayer 1980; Bellwood \& Schultz 1991; Schultz 1993, 2006a, 2006b; Chanet \& Schultz 1994; Carnevale et al. 2012). A comprehensive analysis of the diversity and paleoenvironmental significance of this ichthyofauna is currently in progress.

The Middle Miocene corallinacean limestone exposed in the Neogene Eisenstadt-Sopron Basin is usually referred 
to as Leitha Limestone (Keferstein 1828, Riegl \& Piller 2000). Fossil fishes were collected at the Kummer Quarry, along the Rust Hills, about $2 \mathrm{~km}$ E of St. Margarethen in Burgenland village ( $\left.47^{\circ} 48^{\prime} 01.76^{\prime \prime} \mathrm{N}, 16^{\circ} 37^{\prime} 59.12^{\prime \prime} \mathrm{E}\right)$. A detailed analysis of the stratigraphy and sedimentology of the Kummer Quarry was carried out by Schmid et al. (2001). The ichthyolitiferous layers consist of greenish-whitish calcarenitic marls that originated in a general regime of reduced water energy and hypoxic conditions. The age of these deposits has been established based on the calcareous nannoplankton content, which indicates zone NN5b, around the Langhian/Serravallian boundary, approximately between 14.0 and $13.5 \mathrm{Ma}$, corresponding to the Late Badenian of the Paratethyan stratigraphy (Bulimina-Bolivina Zone of Papp et al. 1978).

\section{Materials and methods}

The specimens are deposited in the Geological-Palaeontological Department of the Natural History Museum, Vienna (NHMW). The available material consists of seven articulated skeletons with bones that appear brown or dark orange, preserved on greenish-withish laminated calcarenitic marls.

The fossils were examined using a Leica MZ6 stereomicroscope equipped with a camera lucida drawing arm. Measurements were taken with a dial calliper, to the nearest $0.1 \mathrm{~mm}$. Some skeletons required matrix removal before examination; this was achieved using thin entomological needles.

Comparative information was derived mainly from the literature (e.g., Svetovidov 1948, 1986; Shcherbachev 1995; Carnevale 2007; Balushkin 2009).

\section{Systematic palaeontology}

Subdivision Teleostei sensu Patterson \& Rosen, 1977

Order Gadiformes Goodrich, 1909

Suborder Gadoidei sensu Endo, 2002

Family Gadidae Rafinesque, 1810

\section{Genus Gaidropsarus Rafinesque, 1810}

\section{Gaidropsarus pilleri sp. nov.}

Figures 1-7, Table 1

Holotype. - NHMW 1988/140/137a+b, nearly complete and well-preserved articulated skeleton in part and counterpart (Fig. 1).

Paratypes. - NHMW 1988/0140/0090a+b, partially complete articulated skeleton in part and counterpart (Fig. 2A, B); NHMW 1976/1812/0141, incomplete articulated skeleton lacking the head and anterior portion of the axial skeleton (Fig. 2C); NHMW 1986/0138/0020a+b, partially complete articulated skeleton in part and counterpart (Fig. 2F, G); NHMW 2000z0135/0113, partially complete articulated skeleton in part and counterpart (Fig. 2J, K).

Type locality and horizon. - St. Margarethen in Burgenland locality; Kummer Quarry; Middle Miocene, Late Badenian (around the Langhian/Serravallian boundary), Bulimina-Bolivina Zone, NN5b zone (see Schmid et al. 2001).

Referred material. - NHMW 1976/1812/0127a+b, partially complete articulated skeleton in part and counterpart (Fig. 2D, E); NHMW 1988/0140/0017a+b, partially complete articulated skeleton in part and counterpart (Fig. 2H, I).

Diagnosis. - A Gaidropsarus with wide neurocranium (neurocranial width contained less than two times in its length); well-developed sphenotic spine; epibranchials 2 and 3 with massive uncinate processes; $44(13+31)$ vertebrae; five posterior parapophyses enlarged; three posterior parapophyses wing-like; $2^{\text {nd }}$ dorsal fin with about 50 rays; anal fin with 43 rays; caudal peduncle very short (2.4\% SL).

Etymology. - It is our pleasure to name this species in honour to the celebrated Austrian palaeontologist Werner E. Piller in recognition of his outstanding contribution to the Mesozoic and Cenozoic palaeontology.

Measurements. - [Based on the holotype NHMW 1988/140/137a+b; standard length (SL): 88.8 mm.] As percentage of SL: maximum body depth: $19.2 \%$; head length: 21.6\%; snout length: $7.3 \%$; mouth gape extension: $12.9 \%$; caudal peduncle length: $2.4 \%$; caudal peduncle depth: $4.8 \%$; predorsal ( $2^{\text {nd }}$ fin) distance: $37 \%$; preanal distance: $50.4 \% ; 2^{\text {nd }}$ dorsal-fin base length: $56.4 \%$; anal-fin base length: $43.8 \%$.

Description. - The body is elongate and relatively slender (Figs 1,2). The maximum body depth is contained more than five times in SL. The head is large and dorsoventrally compressed, its length is contained less than five times in SL. The snout is elongate and nearly tubular. The diameter of the orbit cannot be properly defined because of inadequate preservation. The caudal peduncle is extremely reduced ( $2.4 \% \mathrm{SL})$, its length is contained slightly less than two times in its depth.

The head skeleton exhibits various degrees of disarticulation in the examined specimens, with the bones displaced from their original position and often extensively fragmented and inadequately preserved. The neurocranium is clearly recognizable in most of the available specimens, 

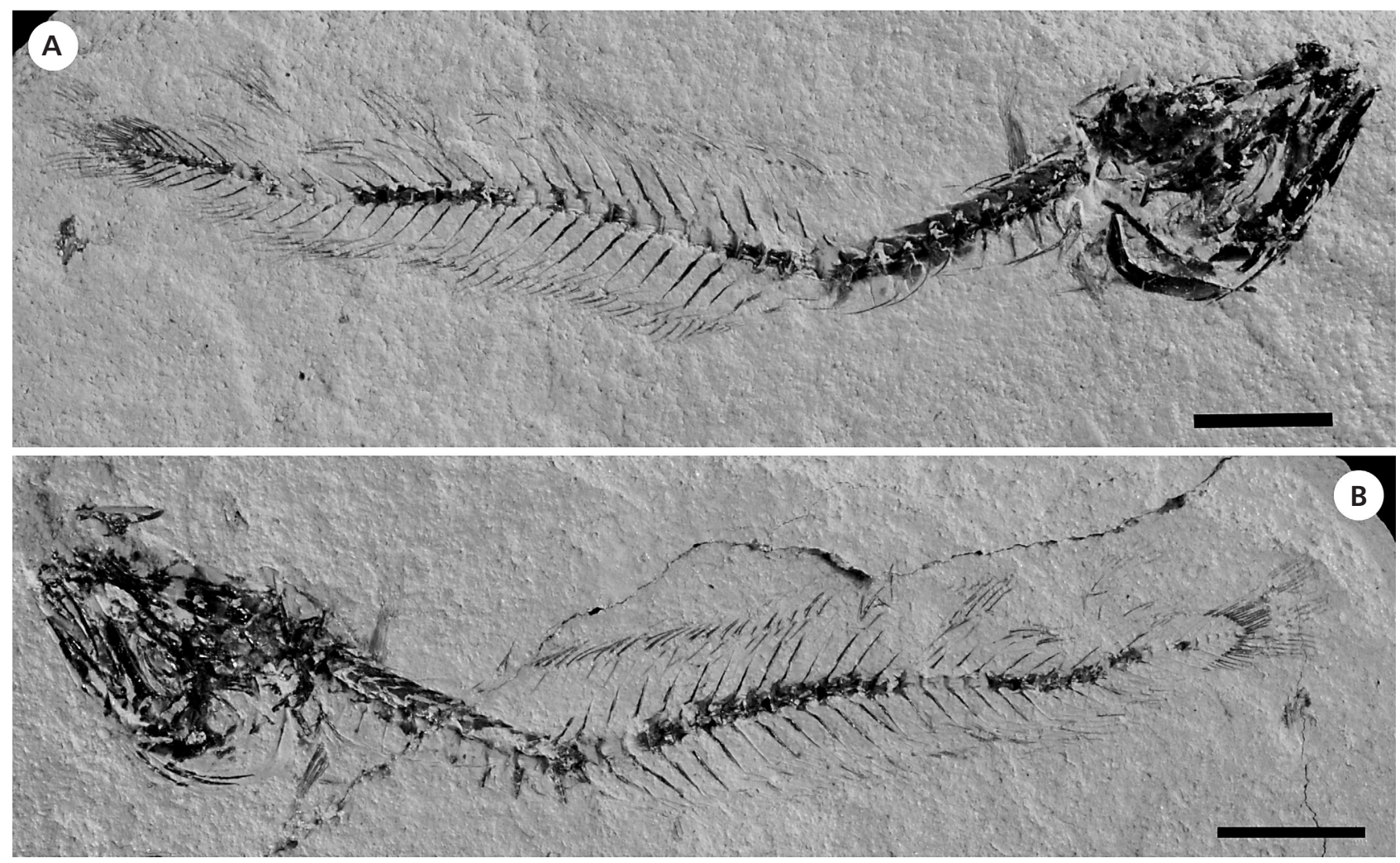

Figure 1. Gaidropsarus pilleri sp. nov. Holotype. • A - NHMW 1988/140/137a; B - NHMW 1988/140/137b. Scale bars 10 mm.

Table 1. Counts for Gaidropsarus pilleri sp. nov.

\begin{tabular}{|c|c|c|c|c|c|}
\hline & vertebrae & $2^{\text {nd }}$ dorsal-fin rays & anal-fin rays & caudal-fin rays & pectoral-fin rays \\
\hline NHMW 1988/140/137a+b & $44(13+31)$ & $? 50$ & 43 & 34 & $17(18)$ \\
\hline NHMW 1976/1812/0127a+b & $44(13+31)$ & $?$ & $?$ & $?$ & $? 17$ \\
\hline NHMW 1988/0140/0090a+b & $?(13+?)$ & $?$ & $?$ & $?$ & $?$ \\
\hline NHMW 2000z0135/0113 & $?$ & $?$ & $?$ & $?$ & $?$ \\
\hline NHMW 1976/1812/0141 & $?(?+31)$ & $?$ & 43 & 36 & $?$ \\
\hline NHMW 1988/0140/0017a+b & $44(13+31)$ & $?$ & $?$ & (33) 34 & $?$ \\
\hline NHMW 1986/0138/0020a+b & ? & ? & $41+?$ & 33 & 17 \\
\hline
\end{tabular}

often exposed in dorsal view (Fig. 3). It is low, with nearly straight dorsal and ventral profiles. The neurocranium is relatively broad; its maximum width measured in the postorbital sector is contained less than two times in the length of its base. The length of the orbitorostral portion of the neurocranium, measured at the level of the sphenotic spine, is slightly shorter than that of the posterior portion. The ethmoid bloc is wide and heavily ossified. The osteological configuration of the neurocranium and the topographic relationships between the bones are identical to those of other congeners (see Svetovidov 1948). The vomer has an angular anterior profile; small recurved vomerine teeth can be observed along the ventral surface of this bone. The anterodorsal portion of the mesethmoid is slightly inflated. The lateral ethmoids bear large lateral processes with a distal end characterized by a rounded profile. The frontals are by far the largest bones of the skull roof; the lateral margins of these bones are notably rounded in the orbital region. The supratemporal lateral line canal is clearly exposed in the paratype NHMW 1988/0140/0090b due to collapse of the overlying frontal crests. The parietals are irregular in shape. The outer surface of the supraoccipital appears to be nearly flat; the supraoccipital crest is reduced (see Howes 1990) and extends posteriorly slightly behind the posterior margin of the neurocranium. Both the sphenotics bear a strong tubular anterolaterally protruding spine. The parasphenoid is a robust straight bone. What appear to be the prootic and intercalar are characterized by a notably convex outer surface. The basioccipital is downcurved posteriorly. 
The gape of the mouth is rather large, apparently reaching the posterior edge of the orbit. The upper jaw projects beyond the anterior tip of the lower jaw. The premaxilla has stout and very robust articular and ascending processes separated from each other by a deep notch, and a thin and pointed postmaxillary process (Fig. 4A); the alveolar process bears a number of small conical teeth with slightly recurved tips arranged in several rows, and a short labial row of six to eight relatively large conical teeth. The maxilla is an elongate bone with a robust and heavily ossified articular head. The dentary is slender and characterized by a short symphyseal process. The teeth of the lower jaw are identical to those of the upper jaw; some of the teeth of the lingual row are considerably larger than the others.

The suspensorium is clearly traceable in the holotype NHMW 1988/140/137 (Fig. 4B, C). The hyomandibula has a single articular head, very long and laminar opercular process and reduced preopercular process (Fig. 4B). The symplectic is large and nearly triangular in outline. The ectopterygoid and endopterygoid are greatly elongate. As in other gaidropsarines, the ventral margins of ectopterygoid and palatine are not continuous along the same line (see Stainier et al. 1986, Endo 2002).

Except for a left preopercle partially exposed in the holotype NHMW 1988/140/137 (see Fig. 4C), the bones of the opercular series are extensively damaged and difficult to interpret. There is a relatively large hyomandibularpreopercle interosseus space (sensu Endo 2002).

The hyoid bar is thick and gently curved. There are six or seven branchiostegal rays all articulating with the anterior ceratohyal.

The branchial skeleton is always disarticulated. The ceratobranchials are elongate and slender. Partially complete dorsal gill arches are recognizable in the holotype NHMW 1988/140/137 (Fig. 5). What appear to be the first, second and third epibranchials possess large and robust uncinate processes. There is no evidence of the first pharyngobranchial. The second, third and fourth pharyngobranchials bear numerous small conical teeth.

The vertebral column comprises 44 vertebrae, of which 13 are abdominal (Table 1). The first abdominal vertebra is closely articulated with the basioccipital. The vertebral centra are thick, subrectangular and longer than high (Figs 1,2). Strong longitudinal ridges and struts are present along the lateral surface of each centrum. Dorsal and ventral prezygapophyses are well-developed along the entire vertebral column, while dorsal postzygapophyses mostly occur in caudal vertebrae. The neural spines of the abdominal vertebrae are anteroposteriorly expanded, strongly thickened and considerably bent backward; their lateral surface is extensively sculptured with shallow irregular pits. The neural spines of caudal centra are slender and nearly straight. The parapophyses of the five posterior abdominal vertebrae are broadly expanded anteroposteriorly and gradually increasing in size; of these, the three posterior are wing-like, each characterized by a central thickened ridge, a straight posterior margin, and pointed distal tip. Abdominal vertebrae four to eight bear short and relatively strong pleural ribs that insert along the ventral margin of the centra through thick and rounded articular heads. Epineurals appear to be exclusive of the abdominal region of the axial skeleton starting from the third vertebra; the first of these slender, elongate and delicate bones appear to be articulated with the ventro-lateral portion of the third vertebra while the following elements originate along the posterior margin of the pleural ribs and, subsequently, of the enlarged parapophyses.

The caudal skeleton is consistent with that of other rocklings (see Monod 1968, Patterson \& Rosen 1989), characterized by two hypural plates (hypurals 1-2 and hypurals 3-5), a parhypural, two epurals and $\mathrm{X}$ and $\mathrm{Y}$ bones (Fig. 6). The caudal fin is rounded and contains 33 to 36 caudal-fin rays. Five caudal-fin rays are supported by the upper hypural plate (hypurals 3-5), and two rays are supported by the lower hypural plate.

The first dorsal fin is not preserved in the available specimens. The second dorsal fin inserts at the level of the $10^{\text {th }}$ vertebra and contains about 50 rays supported by slender pterygiophores.

There is a single anal fin. This originates well behind the second dorsal-fin origin, at the level of the $16^{\text {th }}$ vertebra and consists of 43 rays supported by thin and slender pterygiophores.

The pectoral fin comprises 17 to 18 long rays. Some bones of the pectoral girdle, including the posttemporal and supracleithrum are scarcely preserved in the examined specimens. The cleithrum is a large crescent-shaped bone with a prominent lower limb and a remarkably thickened anterior edge. Scapula and coracoids are partially exposed in the holotype NHMW 1988/140/137 (Fig. 7); the morphology of these bones is consistent with that of extant gaidropsarines (see Stainier et al. 1986, Balushkin 2009); the scapular foramen is located between scapula and coracoids. The postcleithrum is rod-like and slightly curved.

The pelvic fin and girdle cannot be properly recognized due to inadequate preservation.

The body is covered by thin, deciduous cycloid scales.

Taxonomic discussion. - The remarkable quality of the preservation of most of the osteological features in the specimens documented in this paper allowed a well-supported clarification of their taxonomic status.

The descriptive analysis clearly evidenced the gadiform affinity of the seven examined articulated skeletons. The physiognomy of the body and the overall architecture of the skeleton unquestionably indicate that these fossils belong to the order Gadiformes. Moreover, these fossils exhibit some of the gadiform synapomorphies recognized 

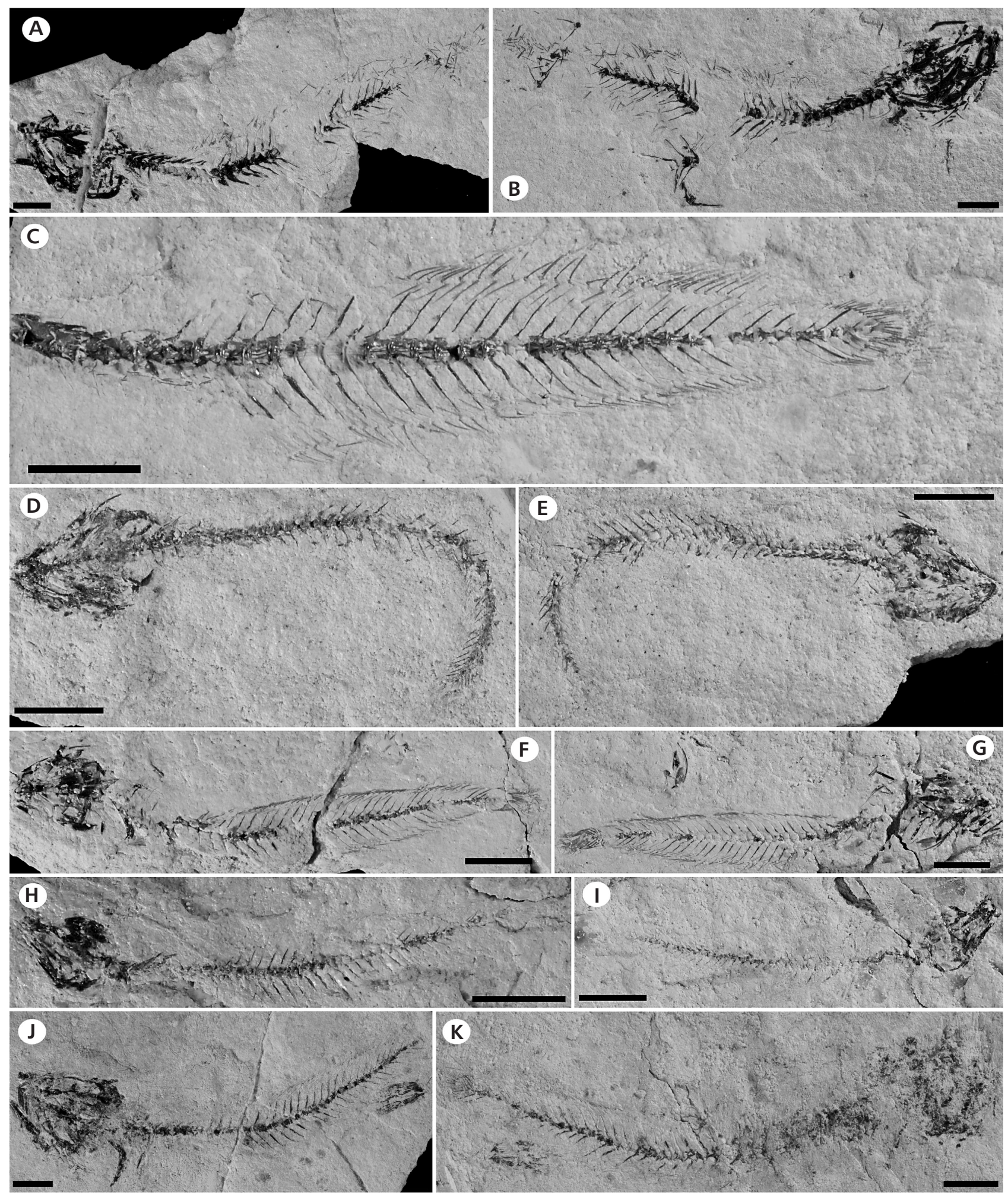

Figure 2. Gaidropsarus pilleri sp. nov. • A - NHMW 1988/0140/0090a, paratype; B - NHMW 1988/0140/0090b, paratype; C - NHMW 1976/1812/0141, paratype; D - NHMW 1976/1812/0127a; E - NHMW 1976/1812/0127b; F - NHMW 1986/0138/0020a, paratype; G - NHMW 1986/0138/0020b, paratype; H - NHMW 1988/0140/0017a; I - NHMW 1988/0140/0017b; J - NHMW 2000z0135/0113a, paratype; K - NHMW 2000z0135/0113b, paratype. Scale bars $10 \mathrm{~mm}$. 


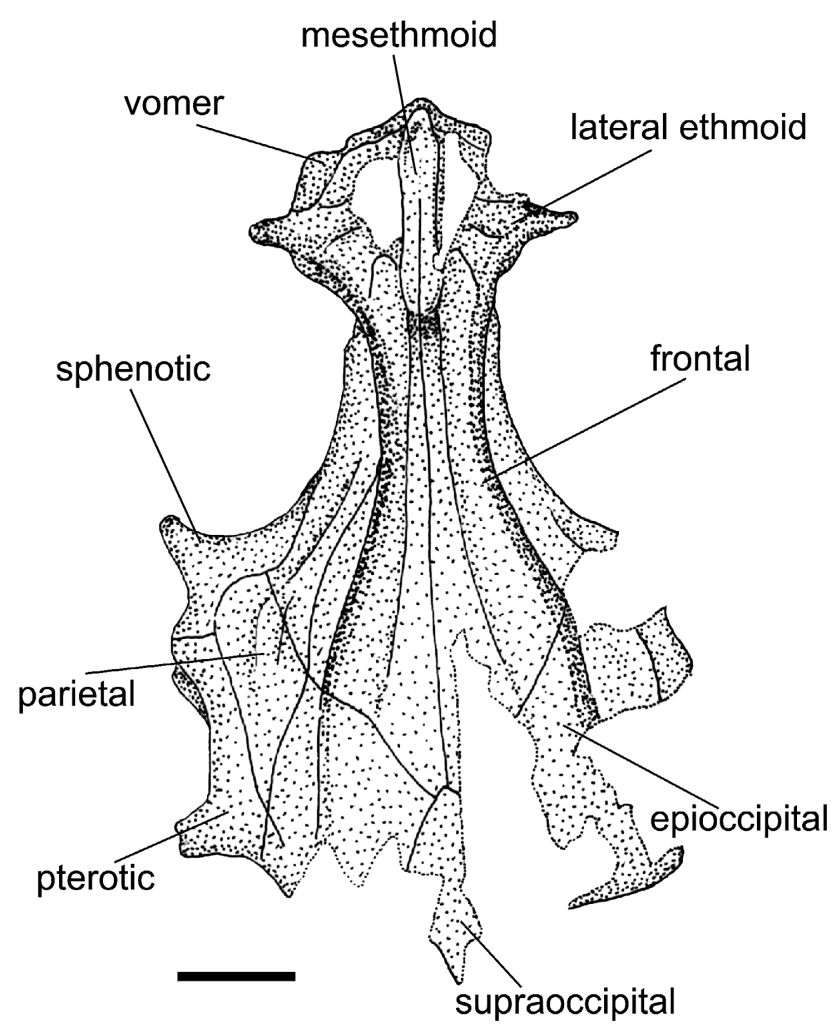

Figure 3. Gaidropsarus pilleri sp. nov. NHMW 1988/0140/0090b, paratype, neurocranium, dorsal view. Scale bar $2 \mathrm{~mm}$.

by several comprehensive studies (e.g., Marshall \& Cohen 1973, Patterson \& Rosen 1989), including the possession of X and Y bones (Markle 1982, Cohen 1984, Fahay \& Markle 1984, Patterson \& Rosen 1989), absence of epineurals on the two anterior abdominal vertebrae (Patterson \& Rosen 1989), scapular foramen located between scapula and coracoids (Endo 2002), and possession of a large hyomandibular-preopercular interosseous space (Okamura 1989, Endo 2002).

Within the Gadiformes, the possession of a large hyomandibular-preopercle interosseous space as well as the presence of two hypural bones in the caudal skeleton clearly indicate that the fossils are members of the suborder Gadoidei (see Markle 1989, Endo 2002, Teletchea et al. 2006). As far as the placement at the family level is concerned, the possession of a rounded caudal fin and the absence of branchiostegal rays on the posterior ceratohyal are clearly indicative of the Gadidae (Endo 2002, Teletchea et al. 2006).

The family Gadidae includes about 30 extant species belonging to 16 genera arranged in four subfamilies, namely the Gadinae, Gaidropsarinae, Lotinae and Phycinae (see Endo 2002, Teletchea et al. 2006). The classification of this group has been traditionally based on the structure of the median fins (see Svetovidov 1948) and subsequently also on meristics and developmental data (see, e.g., Markle 1982, Dunn \& Matarese 1984, Fahay \&
Markle 1984). More recently, Endo (2002) proposed a classification with four subfamilies based on morphological data and Teletchea et al. (2006) reached similar results based on a combined morphological-molecular approach. None of the osteological features recognized by Endo (2002) and Teletchea et al. (2006) as diagnostic of the Gadinae (dorsal shelf of the lachrymal concave; posterior process of the lateral ethmoid secondarily reduced; anterior frontal crests fused; postcleithrum with an expanded proximal end; possession of three dorsal and two anal fins), Lotinae (anterior shift of the palate-vomerine ligament V origin; vomerine head posterolaterally enlarged; absence of process on epibranchial 1) or Phycinae (a single branchiostegal ray articulating on the posterior ceratohyal; basipterygia transversely arrayed; dorsal supernumerary fin rays lost; presence of a ligamentary connection between supracleithrum and anterior appendage of swimbladder) subfamilies can be recognized in the gadid specimens from St. Margarethen in Burgenland documented herein. On the contrary, the specimens clearly exhibit at least one of the gaidropsarine synapomorphies recognized by Teletchea $e t$ al. (2006), five and two caudal-fin rays articulating with the upper and lower hypural plates, respectively. Moreover, at least the holotype NHMW 1988/140/137 shows a unique palatopterygoid configuration, with the ventral margin of palatine and ectopterygoid not continuous (e.g., Stainier et al. 1986), a condition exclusive of gaidropsarines and phycines (Endo 2002). Therefore, on the basis of the osteological evidence, it is possible to assign the seven articulated skeletons described in this paper to the subfamily Gaidropsarinae. The three extant genera belonging to this subfamily share the possession of the muscle anterior rectus ventralis, a peculiar condition of the muscle trasversus ventralis anterior, possession of two to four snout barbels and, more important, the possession of a vibratile first dorsal fin consisting of an elongate pseudospine followed by small unsegmented rays forming a fleshy ridge that rises within a shallow median groove (see Endo 2002, Teletchea et al. 2006). Three of these four characters refer to soft anatomical features that are not prone to fossilization and, as a consequence, not commonly preserved and observable in fossils. The remaining synapomorphic gaidropsarine character, possession of a vibratile first dorsal fin, is not recognizable in the fossils due to inadequate preservation. This structure is extremely delicate and only occasionally has been documented in fossil remains (Carnevale 2007). The thin pterygiophores that support the short unsegmented rays that form most of the first dorsal fin and their associated musculature are unique in being surrounded by a firm capsule of myoseptal collagen (Kotrschal et al. 1984) and are not membraneously connected to each other (Vandewalle et al. 1987); the collagen capsule provides a sort of structural separation from the rest of the axial skeleton that likely favoured a rapid 
ascending process
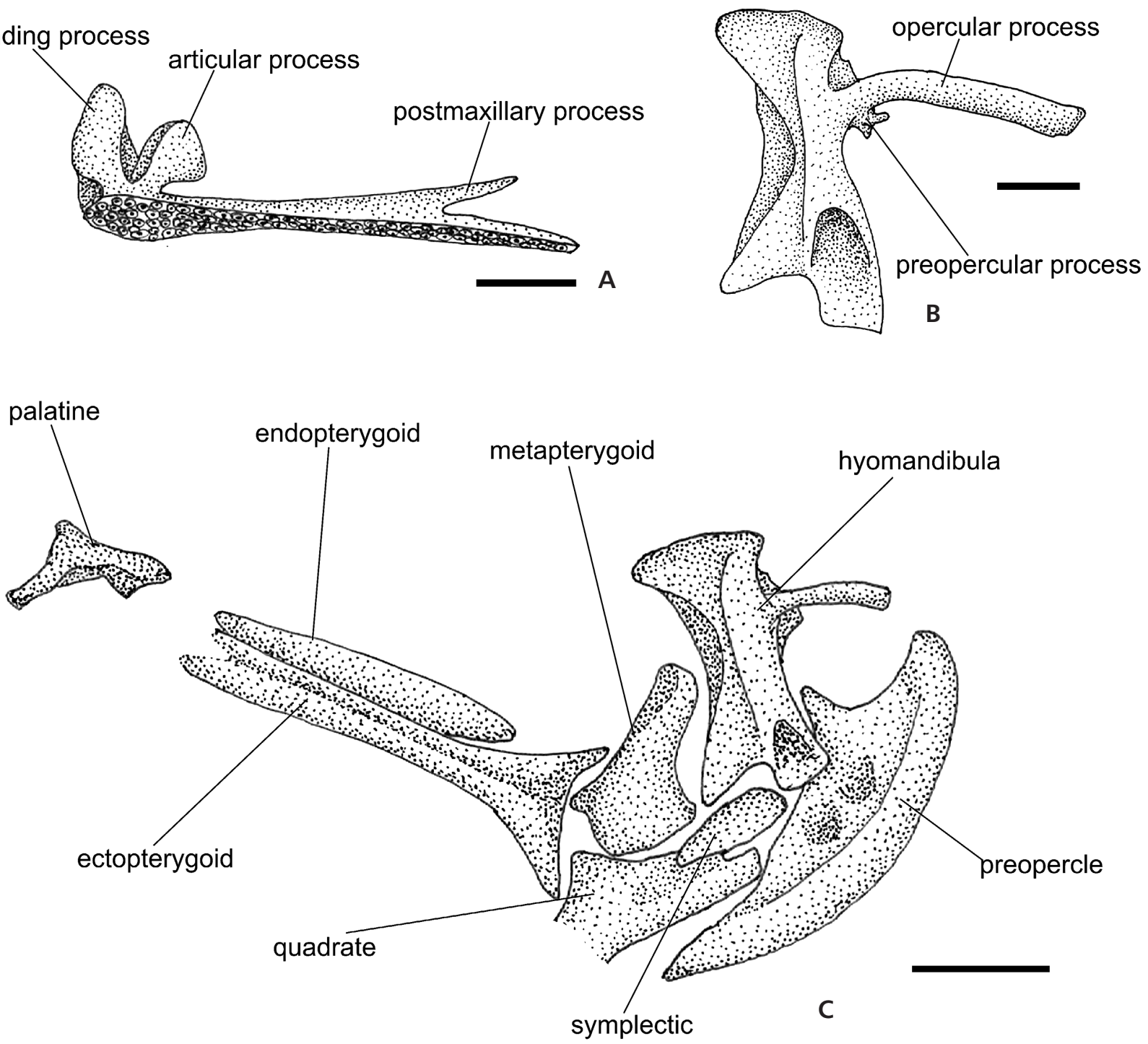

Figure 4. Gaidropsarus pilleri sp. nov. • A - NHMW 2000z0135/0113, paratype, premaxilla, right medial view, scale bar 2 mm; B - NHMW 1986/0138/0020a, paratype, hyomandibula, left lateral view, scale bar 1 mm; C - NHMW 1988/0140/0137b, holotype, suspensorium, left lateral view, scale bar $2 \mathrm{~mm}$.

disarticulation during the early stages of decay after the death of the fish. Such tendency to a precocious disarticulation of the first dorsal fin during the early phases of the fossilization process apparently led to the misidentification of fossil rocklings, which, on the basis of the number of exposed dorsal fins, have been erroneously assigned to certain genera of the Lotinae, such as Brosme (see Kramberger-Gorjanovic 1884, Arambourg 1927), even though the fossil skeletal remains exhibit several osteological and meristic (e.g., fin and vertebral formulae) features clearly indicative of the Gaidropsarinae (see Carnevale 2007).

The subfamily Gaidropsarinae includes 17 species arranged in the three genera Ciliata, Enchelyopus and Gaidropsarus. Wheeler (1969) recognized two additional genera, Antonogadus and Onogadus, which are currently considered as junior synonyms of Gaidropsarus (see Cohen \& Russo 1979). Diagnostic features for the genera of the Gaidropsarinae were defined by Svetovidov (1948), who separated them based on number of barbels and supratemporal pores, and neurocranial and vomerine tooth shape. Cohen \& Russo (1979) claimed that the number of barbels is the only feature that provides unquestionable evidence for the separation of the three genera. Anyway, the number of barbels and supratemporal pores and the shape of the vomerine tooth patch are clearly not recognizable in the fossils documented herein. The neurocranial width appears in some ways similar to that characteristic of the species Ciliata mustela; however, as reported by Cohen \& Russo (1979), the proper evaluation of the diagnostic value of this character will require further examination. 


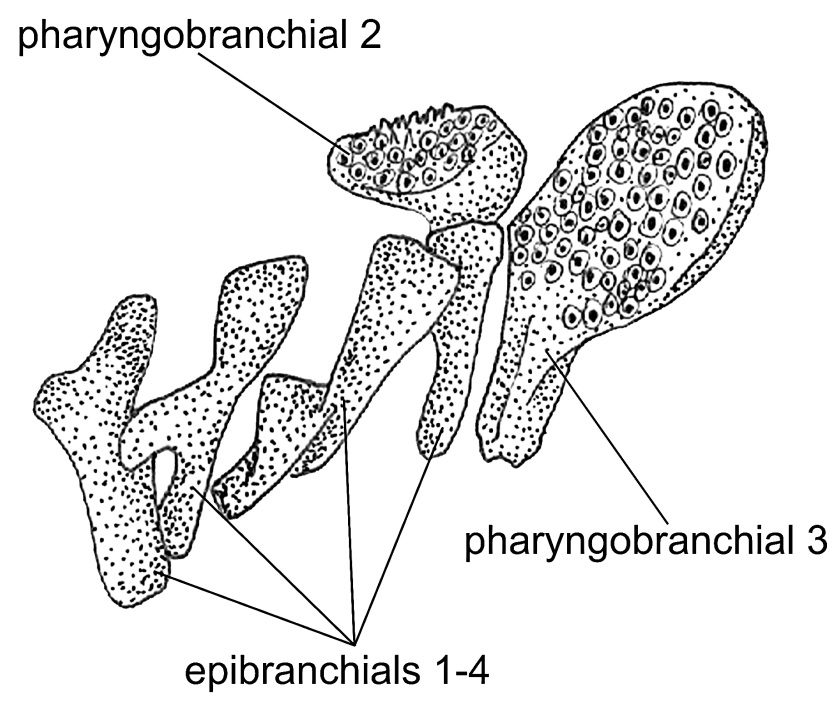

Figure 5. Gaidropsarus pilleri sp. nov. NHMW 1988/140/137a, holotype, partially complete dorsal gill arches, right series, ventral view. Scale bar $2 \mathrm{~mm}$.

The fossil gaidropsarines described in this paper are assigned to the genus Gaidropsarus because of the possession of greatly enlarged parapophyses and broad and angular vomerine head. According to Svetovidov (1948), the possession of enlarged parapophyses is characteristic of Gaidropsarus species while the genera Ciliata and Enchelyopus have narrow and short parapophyses.

With 14 known species, the genus Gaidropsarus is the most speciose of the subfamily Gaidropsarinae (see Svetovidov 1986, Shcherbachev 1995, Carnevale 2007, Balushkin 2009). The Miocene Gaidropsarus pilleri sp. nov. from St. Margarethen in Burgenland described in this paper differs from all the species of the genus, except G. biscayensis and G. capensis, by its vertebral, dorsal-, anal-, and pectoral-fin complements (see Table 2). It differs from both G. biscayensis and G. capensis by having a shorter caudal peduncle $(2.4 \%$ SL vs $6.4-7.5 \%$ SL in G. capensis and 3.9-6.0\% SL in G. biscayensis; Svetovidov 1986). Moreover, the Miocene species from St. Margarethen in Burgenland is unique within the genus Gaidropsarus by having a wider neurocranium with well developed anterolaterally directed sphenotic spines. Additional peculiar features observed in Gaidropsarus pilleri sp. nov. include the presence of massive uncinate processes in the epibranchials 2 and 3 , and the possession of enlarged parapophyses on the five posteriormost abdominal vertebrae, of which the posterior three are wing-like.

\section{Concluding remarks}

Gaidropsarus pilleri sp. nov. from the Middle Miocene calcarenitic laminated marls outcropping in the surroundings of St. Margarethen in Burgenland constitutes the earliest skeletal record of the genus Gaidropsarus and, more generally, of the whole subfamily Gaidropsarinae. The earliest stages of the evolutionary history of this group of gadid fishes, however, are better documented in the otolith record, which documents the occurrence of Gaidropsarus since the Rupelian (Nolf \& Steurbaut 1989). The Early Oligocene existence of gaidropsarines is consistent with that of its sister, the Phycinae, which also appeared in the Rupelian (see Nolf \& Steurbaut 1989). Therefore, the gaidropsarine body plan dates back at least to the lower part of the Oligocene, a time interval characterized by a conspicuous radiation of gadid fishes, with the appearance of several

Table 2. Synopsis of meristic values of fossil and extant species of the genus Gaidropsarus. Data from Svetovidov (1986) and Carnevale (2007).

\begin{tabular}{|c|c|c|c|c|c|}
\hline & vertebrae & $2^{\text {nd }}$ dorsal-fin rays & anal-fin rays & caudal-fin rays & pectoral-fin rays \\
\hline Gaidropsarus pilleri sp. nov. & 44 & 50 & 43 & $33-36$ & $17-18$ \\
\hline Gaidropsarus argentatus & $51-53$ & $54-62$ & $43-51$ & $?$ & $22-24$ \\
\hline Gaidropsarus biscayensis & $44-47$ & $48-52$ & $40-45$ & $?$ & $18-20$ \\
\hline Gaidropsarus capensis & $41-43$ & $46-49$ & $39-43$ & $?$ & $18-20$ \\
\hline Gaidropsarus ensis & 52 & $53-62$ & $41-48$ & $?$ & $22-25$ \\
\hline Gaidropsarus granti & $?$ & 60 & 48 & $?$ & 21 \\
\hline Gaidropsarus guttatus & $49-50$ & $53-57$ & $48-50$ & $?$ & $17-19$ \\
\hline Gaidropsarus insularum & $47-49$ & $66-70$ & 57 & $?$ & $19-22$ \\
\hline Gaidropsarus macrophthalmus & $45-47$ & $53-58$ & $45-49$ & $?$ & $17-19$ \\
\hline Gaidropsarus mediterraneus & $47-50$ & $54-58$ & $44-49$ & $?$ & $16-19$ \\
\hline Gaidropsarus murdjadjensis & $?$ & $?$ & $?$ & $?$ & 16 \\
\hline Gaidropsarus novaezelandiae & $46-49$ & $55-69$ & $50-59$ & $?$ & $20-21$ \\
\hline Gaidropsarus pakhorukovi & $46-47$ & 62 & 51 & 38 & 25 \\
\hline Gaidropsarus parini & 47 & $60-63$ & 53 & $35-37$ & $23-25$ \\
\hline Gaidropsarus vulgaris & $48-49$ & $59-62$ & $48-53$ & $?$ & $21-22$ \\
\hline
\end{tabular}


Figure 6. Gaidropsarus pilleri sp. nov. NHMW 1976/1812/0141, paratype, caudal skeleton, left lateral view. Scale bar $1 \mathrm{~mm}$.

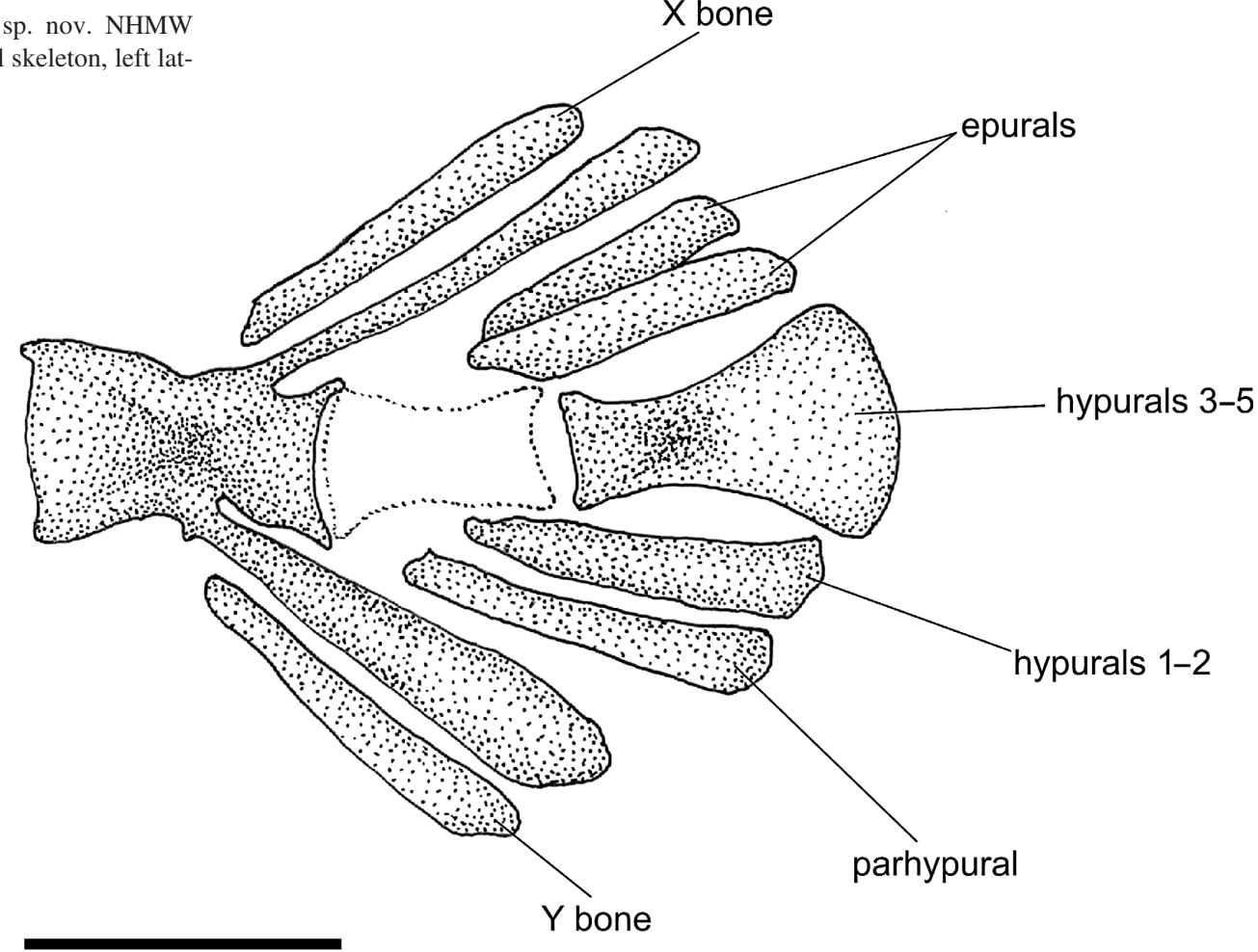

lineages (see Fedotov \& Bannikov 1989, Nolf \& Steurbaut 1989).

Despite its problematic observation in fossil specimens, the vibratile first dorsal fin certainly represents the most salient feature of the gaidropsarine body plan (see Endo 2002). This structure is a highly modified version of the plesiomorphic gadiform first dorsal fin and is characterized by a prominent anterior pseudospine behind which several soft rays project from a strongly reduced fin web as a fringe of short thin filaments. Cohen \& Russo (1979) considered the prominent pseudospine and the subsequent series of delicate filaments as homologues of the first and second dorsal fins of other gadine fishes, respectively. Such hypothesis is not supported by anatomical and ontogenetic evidence. The second and third dorsal fins of gadines are separated only externally, characterized by a continuous pterygiophore series between them (see Markle 1982); such an internal structural continuity of these fins suggests that they should be regarded as the product of an external fragmentation of the second dorsal fin, thereby implying that the second and third dorsal fins of gadines are homologous of the continuous second dorsal fin of other gadids and, more generally, of other gadiform fishes. Therefore, the entire first dorsal fin of gaidropsarines should be considered as homologous of the first dorsal fin of the other gadiforms.

The anatomical structure of the peculiar anterior dorsal fin of gaidropsarines has been described by several authors (e.g., Bateson 1890; Bogoljubsky 1908; Thomson 1912;
Crisp et al. 1975; Kotrschal et al. 1984, 1985, 1993; Peters et al. 1987; Vandewalle et al. 1987; Kotrschal \& Whitear 1988; Whitear \& Kotrschal 1988; Kotrschal \& Finger 1996). The pseudospine bears a number of taste buds and the epidermis of the thin and short filamentous rays contains millions of solitary chemosensory cells. The entire first dorsal fin is innervated by branches of the recurrent facial nerve and by spinal nerves. The nervus recurrens facialis sends branches to the pectoral, pelvic and dorsal fins. The branches that innervate the first dorsal fin are joined by branches from the dorsal ramuli of spinale nerves and pass through the wall of the capsule of collagenous connective tissue that encloses the supporting elements of the fin and their associated muscles (Kotrschal et al. 1985). Overall, the first dorsal fin of gaidropsarines constitutes specific sensory organ, a sort of water sampler, representing a unique novelty (in the sense of Hall \& Kerney 2012) within the Teleostei. Each ray is moved by two pairs of muscles, the erectores and depressores. The lateral movements of the rays are allowed by the erectores muscles and maintain the fin in a constant undulation that draws sea water towards and through the fin rays and backwards as a slightly perceptible current (see Kotrschal et al. 1984, Vandewalle et al. 1987). According to Kotrschal et al. (1985), the selective advantage acting during the evolution of this chemosensory organ was the ability to detect prey among the animals living on the area surrounding the fish in its living habitat.

The origin of such a spectacular morphological innovation is really difficult to interpret. According to Mabee 


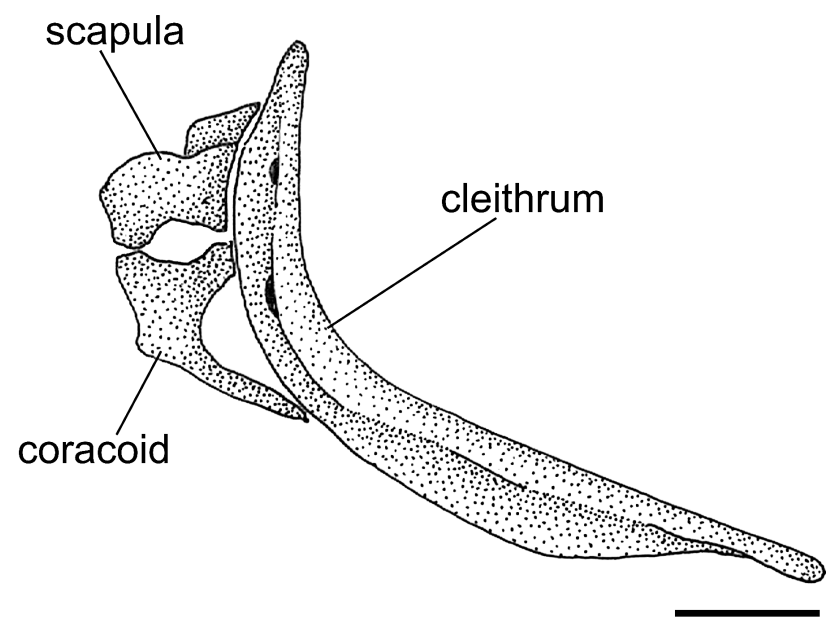

Figure 7. Gaidropsarus pilleri sp. nov. NHMW 1988/0140/137a, holotype, pectoral girdle, right lateral view. Scale bar $2 \mathrm{~mm}$.

et al. (2002), the dorsal fins can be regarded as discrete developmental modules. Mabee et al. (2002) hypothesized that the spinous first dorsal fin of acanthomorph fishes (including gadiforms) essentially represents an anterior duplication of the posterior soft-rayed dorsal fin. Modular organization enhances the possibility of duplication and divergence of discrete and anatomically regionalized structures (see Gilbert 2010), since duplication may result in the origin of redundant structures and divergence allows them to assume new anatomical or functional roles. As evidenced by Mabee et al. (2002), the regionally specialized spinous dorsal fin may revert secondarily to a spine-less condition in some acanthomorph lineages, including flatfishes and dolphinfishes. The Gadiformes possibly represents a further group characterized by such a secondary reversion, even considering that the first dorsal fin of the basal gadiform Melanonus exclusively comprises soft rays (see Howes 1993). From a structural point of view, the first and second dorsal fins of most gadiforms are nearly identical to each other, suggesting that their respective modules usually do not follow divergent evolutionary trajectories. On the other hand, the vibratile first dorsal fin of gaidropsarines possibly represents a case of decoupled developmental modularity. However, considering the unspecialized first dorsal fin that occurs in most gadiform lineages, it is difficult to believe that the highly specialized, chemosensory and vibratile first dorsal fin of gaidropsarines solely represents the evolutionary product of duplication and divergence of a single dorsal fin module. Instead, like the first dorsal fin of actinistians, chimaeroids and symmoriform sharks (see Maisey 2009), that of gaidropsarines possibly constitutes an example of co-option (in the sense of Raff 1996), which involves both morphological and functional transformation of a pre-existing first dorsal fin module (Maisey 2009).

\section{Acknowledgements}

We are grateful to Walter Landini (Dipartimento di Scienze della Terra, Università di Pisa, Pisa) for its precious suggestions and to Federica Giudice for improvement of the English. Thanks are also due to Ortwin Schultz and Thomas Nichterl (NHMW) for technical support and to Alice Schumacher (NHMW) for the photographs. For reviewing the manuscript and providing constructive suggestions for its improvement we are particularly grateful to Alexandre F. Bannikov (Borysiak Paleontological Institute, Russian Academy of Sciences, Moscow) and Tomáš Přikryl (Institute of Geology, Academy of Sciences of the Czech Republic, Prague). The research of the senior author was supported by the SYNTHESYS grants of the Naturhistorisches Museum Wien.

\section{References}

Arambourg, C. 1927. Les poissons fossiles d'Oran. Matériaux pour la Carte géologique de l'Algérie, lère série, Paléontologie 6, 1-218.

BACHMAYER, F. 1980. Eine fossile Schalgennadel (Syngnathidae) aus dem Leithakalk (Badenien) von St. Margarethen, Burgerland (Österreich). Annalen des Naturhistorischen $\mathrm{Mu}$ seums in Wien 83, 29-33.

BALushkin, A.V. 2009. On the first occurrence of the rockling Gaidropsarus pakhorukovi Shcherbachev (Gaidropsarini, Lotinae, Gadidae) and on species diagnostic of G. pakhorukovi and G. parini Svetovidov. Journal of Ichthyology 49, 723-729. DOI 10.1134/S0032945209090033

BAteson, W. 1890. The sense-organs and perceptions of fishes; with remarks on the supply of bait. Journal of the Marine Biological Association of the United Kingdom 1, 225-256. DOI 10.1017/S0025315400072118

Bellwood, D.R. \& Schultz, O. 1991. A review of the fossil record of the parrotfishes (Labroidei: Scaridae), with a description of a new Calotomus species from the Middle Miocene (Badenian) of Austria. Annalen des Naturhistorischen Museums in Wien 92 A, 55-71.

Bogoljubsky, S. 1908. Zur Kenntnis der Dorsalflosse bei Motella tricirrata. Zeitschrift für wissenschaftliche Zoologie 90, 327-333.

Carnevale, G. 2007. New gadiform fishes (Teleostei, Gadiformes) from the Miocene of Algeria. Journal of African Earth Sciences 47, 95-111.

DOI 10.1016/j.jafrearsci.2006.12.003

Carnevale, G., Harzhauser, M. \& Schultz, O. 2012. The Miocene gadid fish Palimphemus anceps Kner, 1862: a reappraisal. Geodiversitas 34, 625-643. DOI 10.5252/g2012n3a9

Chanet, B. \& Schultz, O. 1994. Pleuronectiform fishes from the Upper Badenian (Middle Miocene) of St. Margarethen (Austria). Annalen des Naturhistorischen Museums in Wien 96 A, 95-115.

Cohen, D.M. 1984. Gadiformes: overview, 259-265. In Moser, H.G., Richards, W.J., Cohen, D.M., Fahay, M.P., Kendall, A.W. JR. \& RichaRdSON, S.L. (eds) Ontogeny and systematics of fishes. American Society of Ichthyologists and Herpetologists, Special Publication 1. 
Cohen, D.M. \& Russo, J.L. 1979. Variation in the fourbeard rockling, Enchelyopus cimbrius, a North Atlantic gadid fish, with comments on the genera of the rocklings. Fishery Bulletin 77, 91-104.

CrisP, M., Lowe, G.A. \& Laverack, M.S. 1975. On the ultrastructure and permeability of the taste buds in the marine teleost Ciliata mustela. Tissue and Cell 7, 191-202.

DOI 10.1016/S0040-8166(75)80016-4

DunN, J.R. \& MAtARESE, A.C. 1984. Gadidae: development and relationships, 283-299. In Moser, H.G., Richards, W.J., Cohen, D.M., Fahay, M.P., Kendall, A.W. JR. \& Richardson, S.L. (eds) Ontogeny and systematics of fishes. American Society of Ichthyologists and Herpetologists, Special Publication 1.

Endo, H. 2002. Phylogeny of the Order Gadiformes (Teleostei, Paracanthopterygii). Memoirs of the Graduate School of Fisheries Sciences, Hokkaido University 49, 75-149.

FAHAY, M.P. \& MARKLE, D.F. 1984. Gadiformes: development and relationships, 265-283. In Moser, H.G., RichardS, W.J., Cohen, D.M., FAhay, M.P., Kendall, A.W. JR. \& Richardson, S.L. (eds) Ontogeny and systematics of fishes. American Society of Ichthyologists and Herpetologists, Special Publication 1.

Fedotov, V.F. \& Bannikov, A.F. 1989. On the phylogenetic relationships of fossil Gadidae, 187-196. In CoHEN, D.M. (ed.) Papers on the Systematics of Gadiform Fishes. Science Series, Natural History Museum of the Los Angeles County 32.

GilBert, S.F. 2010. Developmental Biology. 711 pp. Sinauer Associates, Inc., Sunderland.

Goodrich, E.S. 1909. Vertebrata craniata. Fascicule I. Cyclostome and fishes, 1-518. In LANKeSter, E.R. (ed.) A Treatise on Zoology. Part 9. Adam \& Charles Black, London.

HaLl, B.K. \& KeRNEY, R. 2012. Levels of biological organization and the origin of novelty. Journal of Experimental Zoology (Mol Dev Evol) 318, 428-437. DOI 10.1002/jez.b.21425

HeCKel, J.J. 1850. Beiträge zur Kenntniss der fossilen Fische Oesterreichs. I. Denkschriften der Akademie der Wissenschaften, Mathematisch-naturwissenshaftliche Klasse 1, 201-242.

Heckel, J.J. 1856. Beiträge zur Kenntniss der fossilen Fische Österreichs. Denkschriften der Akademie der Wissenschaften, Mathematisch-naturwissenshaftliche Klasse 11, 187-274.

Heckel, J.J. \& KNER, R. 1861. Neue Beiträge zur Kenntnis der fossile Fische Österreichs. Denkschriften der Akademie der Wissenschaften, Mathematisch-naturwissenshaftliche Klasse 19, 49-76.

Howes, G.J. 1990. The syncranial osteology of the southern eel-cod family Muraenolepididae, with comments on its phylogenetic relationships and on the biogeography of SubAntarctic gadoid fishes. Zoological Journal of the Linnean Society 100, 73-100. DOI 10.1111/j.1096-3642.1990.tb01861.x

Howes, G.J. 1991. Biogeography of gadoid fishes. Journal of Biogeography 18, 595-622. DOI 10.2307/2845542

Howes, G.J. 1993. Anatomy of the Melanonidae (Teleostei: Gadiformes), with comments on its phylogenetic relationships. Bulletin of the Natural History Museum (Zoology) 59, $11-31$.

Keferstein, C. 1828. Beobachtungen und Ansichten über die geognostischen Verhältnisse der nördlichen Kalk-Alpenkette in Österreich-Bayern. Teutschland geognostisch-geologisch dargestellt 5(3), 1-425.

KNER, R. 1862. Kleinere Beiträge zur Kenntnis der fossilen Fische Österreichs. Sitzungsberichte der Kaiserlichen Akademie der Wissenschaften, Mathematisch-naturwissenshaftliche Klasse, Abteilung I 45, 485-498.

Kotrschal, K. \& Finger, T.E. 1996. Secondary connections of the dorsal and ventral facial lobes in a teleost fish, the rockling (Ciliata mustela). The Journal of Comparative Neurology 370, 415-426.

DOI 10.1002/(SICI)1096-9861(19960708)370:4<415::AID-C $\mathrm{NE} 1>3.0 . \mathrm{CO} ; 2-7$

Kotrschal, K., Goldschmid, A., Adam, H. \& Whitear, M. 1985. The first dorsal fin of Gaidropsarus mediterraneus (Teleostei), a specialized chemosensory organ. Fortschritte der Zoologie 30, 727-730.

Kotrschal, K. \& Whitear, M. 1988. Chemosensory anterior dorsal fin in rocklings (Gaidropsarus and Ciliata, Teleostei, Gadidae): Somatotopic representation of the Ramus Recurrens Facialis as revealed by transganglionic transport of HRP. The Journal of Comparative Neurology 268, 109-120.

DOI 10.1002/cne.902680111

Kotrschal, K., Whitear, M. \& Adam, H. 1984. Morphology and histology of the anterior dorsal fin of Gaidropsarus mediterraneus (Pisces, Teleostei), a specialized sensory organ. Zoomorphology 104, 365-372.

DOI 10.1007/BF00312187

Kotrschal, K., Whitear, M. \& Finger, T.E. 1993. Spinal and facial innervation of the skin in the gadid fish Ciliata mustela (Teleostei). The Journal of Comparative Neurology 331, 407-417. DOI 10.1002/cne.903310310

Kramberger-GorJANOvic, D. 1884. Die Jungtertiäre Fischfauna Croatiens. Beiträge zur Paläontologie Österreich-ungars und des Orients 3, 65-85.

Mabee, P.M., Crotwell, P.L., Bird, N.C. \& Burke, A.C. 2002. Evolution of median fin modules in the axial skeleton of fishes. Journal of Experimental Zoology (Mol Dev Evol) 294, 77-90. DOI 10.1002/jez.10076

MaISEY, J.G. 2009. The spine-brush complex in symmoriform sharks (Chondrichthyes; Symmoriformes), with comments on dorsal fin modularity. Journal of Vertebrate Paleontology 29, 14-24. DOI 10.1671/039.029.0130

Markle, D.F. 1982. Identification of larval and juvenile Canadian Atlantic gadoid with comments on the systematics of gadid subfamilies. Canadian Journal of Zoology 60, 3420-3438. DOI 10.1139/z82-432

MARKLE, D.F. 1989. Aspects of character homology and phylogeny of Gadiformes, 59-88. In COHEN, D.M. (ed.) Papers on the Systematics of Gadiform Fishes. Science Series, Natural History Museum of the Los Angeles County 32.

Marshall, N.B. \& Cohen, D.M. 1973. Order Anacanthini (Gadiformes): characters and synopsis of families, 479-495. In COHEN, D.M. (ed.) Fishes of the Western North Atlantic. Memoirs of the Sears Foundation for Marine Research 6.

Monod, T. 1968. Le Complexe Urophore des Poissons Téléostéens. Memoires de l'Institut Fondamentale de l'Afrique Noire 81, 1-705.

MünSter, Graf G. Zu 1846. Ueber die in der Tertiär-Formation des Wiener Beckens vorkommenden Fisch-Ueber-reste, mit 
Beschreibung eininger neuen merkwürdingen Arten. Beiträge zur Petrefactenkunde 7, 1-31.

Nolf, D. \& Steurbaut, E. 1989. Importance and restriction of the otolith-based fossil record of gadiform and ophidiiform fishes, 47-58. In Cohen, D.M. (ed.) Papers on the Systematics of Gadiform Fishes. Science Series, Natural History Museum of the Los Angeles County 32.

OKamuRA, O. 1989. Relationships of the suborder Macruroidei and related groups, with comments on Merlucciidae and Steindachneria, 129-142. In CoHEN, D.M. (ed.) Papers on the Systematics of Gadiform Fishes. Science Series, Natural History Museum of the Los Angeles County 32.

Papp, A., Cicha, I., Senes, J. \& Steininger, F. 1978. M4 Badenian (Moravien, Wielicien, Kosovien). Chronostratigraphie und Neostratotypen. Miozän der Zentralen Paratethys 6, 1-594.

Patterson, C. \& Rosen, D.E. 1977. Review of ichthyodectiform and other Mesozoic teleost fishes and the theory and practice of classifying fossils. Bulletin of the American Museum of Natural History 158, 81-172.

Patterson, C. \& Rosen, D.E. 1989. The Paracanthopterygii revisited: order and disorder, 6-36. In CoHEN, D.M. (ed.) Papers on the Systematics of Gadiform Fishes. Science Series, Natural History Museum of the Los Angeles County 32.

Peters, R.C., Vansteenderen, G.W. \& Kotrschal, K. 1987. A chemoreceptive function of the anterior dorsal fin in rocklings (Gaidropsarus and Ciliata: Teleostei: Gadidae): Electrophysiological evidence. Journal of the Marine Biological Association of the United Kingdom 67, 819-823. DOI 10.1017/S0025315400057064

RAFF, R.A. 1996. The shape of life. 520 pp. Chicago University Press, Chicago.

RAFINESQUE, C.S. 1810. Indice d'ittiologia siciliana; ossia, catalogo metodico dei nomi latini, italiani, e siciliani dei pesci, che si rinvengono in Sicilia disposti secondo un metodo naturale e seguito da un'appendice che contiene la descrizione di alcuni nuovi pesci siciliani. Messina.

Riegl, B. \& Piller, W.E. 2000. Biostromal coral facies - a Miocene example from the Leitha Limestone (Austria) and its actualistic interpretation. PALAIOS 15, 399-413. DOI 10.1669/0883-1351(2000)015<0399:BCFAME $>2.0 . C O ; 2$

Schmid, H.P., Harzhauser, M. \& Kroh, A. 2001. Hypoxic Events on a Middle Miocene Carbonate Platform of the Central Paratethys (Austria, Badenian, $14 \mathrm{Ma}$ ), with contributions by Coric, S., Rögl, F. \& Schultz, O. Annalen des Naturhistorischen Museums in Wien 102 A, 1-50.
Schultz, O. 1993. Der Nachweis von Scorpaena s.s. (Pisces, Teleostei) im Badenien von St. Margarethen, Burgenland, Österreich. Revision von Scorpaena prior Heckel in Heckel \& Kner, 1861. Annalen des Naturhistorischen Museums in Wien 95 A, 127-177.

Schultz, O. 2006a. Rasiermesserfische (Aeoliscus: Centriscidae: Osteichthyes) aus dem Badenien (Mittel-Miozän) von St. Margarethen im Burgenland, Österreich (Zentrale Paratethys). Annalen des Naturhistorischen Museums in Wien 107 A, 71-85.

Schultz, O. 2006b. An Anglerfish, Lophius (Osteichthyes, Euteleostei, Lophiidae), from the Leitha Limestone (Badenian, Middle Miocene) of the Vienna Basin, Austria (Central Paratethys). Beiträge zur Paläontologie 30, 427-435.

SHCHERBACHEV, Y.N. 1995. New species of rockling, Gaidro psarus pakhorukovi (Gadidae), from the Rio Grande Rise (Southwest Atlantic). Journal of Ichthyology 35, 233-235.

Stainier, F., Chardon, M. \& Vandewalle, P. 1986. Os, muscles et ligaments de la region céphalique de Ciliata mustela (Linne, 1758) (Pisces, Gadidae). Cybium 10, 327-349.

Svetovidov, A.N. 1948. Treskoobraznye [Gadiformes]. Fauna SSSR, Zoologicheskii Institut Akademii Nauk SSSR 34, Ryby [Fishes] 9(4), 1-222. [in Russian; English translation 1962: 304 pp. Israel Program for Scientific Translation, Jerusalem]

Svetovidov, A.N. 1986. Review of the three-bearded rocklings of the genus Gaidropsarus Rafinesque, 1810 (Gadidae) with description of a new species. Journal of Ichthyology 26, 114-135.

Teletchea, F., Laudet, V. \& Hänni, C. 2006. Phylogeny of the Gadidae (sensu Svetovidov, 1948) based on their morphology and two mitochondrial genes. Molecular Phylogenetics and Evolution 38, 189-199. DOI 10.1016/j.ympev.2005.09.001

Thomson, J.S. 1912. The dorsal vibratile fin of the rockling (Motella). Quarterly Journal of the Microscopical Society 58, 241-256.

Vandewalle, P., Stainier, F. \& Chardon, M. 1987. Morphology and movements of the first dorsal fin of the rockling, Motella mustela (Linné, 1758) (Pisces, Gadiformes). Zoologischer Anzeiger 218, 266-272.

WHEELER, A.C. 1969. The fishes of the British Isles and NorthWest Europe. 613 pp. Mcmillan, London.

WhITEAR, M. \& KotRSCHAL, K. 1988. The chemosensory anterior dorsal fin in rocklings (Gaidropsarus and Ciliata, Teleostei, Gadidae): activity, fine structure and innervation. Journal of Zoology, London 216, 339-366. DOI 10.1111/j.1469-7998.1988.tb02434.x 